\title{
WOMEN'S READING AND WRITING PRACTICES: CHICK-LIT AS A SITE OF STRUGGLE IN POPULAR CULTURE AND LITERATURE
}

\author{
Burcu Baykan* \\ *Ms., Doctoral Researcher in Trinity College Dublin, Ireland, baykanb@tcd.ie
}

\begin{abstract}
This paper represents an exploration into "chick-lit" literature and its significance in the popular cultural context. As a genre of popular literature written for young urban women, the tremendous commercial success of the popular chick-lit fiction inevitably calls for a critical assessment of its status within popular culture and literature. This paper aims to explore the genre's significance for the research about popular literature, its relationship to literary and scholarly criticism, as well as women's reading and writing practices. By focusing on the production, consumption and reception of chick-lit as a global feminine genre, the paper presents the main characteristics of chick-lit fiction and its differences from other genres such as conventional romances. It also highlights the strengths and limitations of the genre in relation to literary values and cultural standards. Chick-lit's incredible popularity as a cultural and literary phenomenon is further investigated by drawing upon several critical debates introduced by Lawrence W. Levine, Stuart Hall, John Fiske and Michel de Certeau. This paper also considers chick-lit as a deeply contradictory genre of literature that generates highly polarized responses, thus as a site of continuous struggle between "consent and resistance" (Hall 466). To view chick-lit either from an entirely negative or positive perspective would be to oversimplify both the genre and the issues related to literature. Therefore, by considering chick-lit's both wide appeal to its readers and denunciation by literary critics as trivial fiction, and exploring the positions taken up in academic and popular discussions about the genre, the paper seeks to examine the polarized responses and the questions chick-lit raises regarding literature, popular culture and contemporary sociocultural realities of women.
\end{abstract}

Keywords: Chick-lit, popular culture, literary criticism, women's fiction, cultural studies.

\section{INTRODUCTION}

This paper represents an exploration into "chick-lit" literature and its significance in the popular cultural context. It aims to explore the genre's significance for the research about popular literature, its relationship to literary and scholarly criticism, as well as women's reading and writing practices. By focusing on the production, consumption, and reception of chick-lit as a global feminine genre, the paper presents the main characteristics of chick-lit fiction and its differences from other genres such as conventional romances. It also highlights the strengths and limitations of the genre in relation to literary values and cultural standards. Chick-lit's incredible popularity as a cultural and literary phenomenon is further investigated by drawing upon several critical debates introduced by Lawrence W. Levine, Stuart Hall, John Fiske and Michel de Certeau. This paper also considers chick-lit as a deeply contradictory genre of literature that generates highly polarized responses, thus as a site of continuous struggle between "consent and resistance" (Hall 466). To view chick-lit either from an entirely negative or positive perspective would be to oversimplify both the genre and the issues related to literature. Therefore, considering chick-lit's both wide appeal to its readers and denunciation by literary critics as trivial fiction, and exploring the positions taken up in academic and popular discussions about the genre, the paper seeks to examine the polarized responses and the questions chick-lit raises regarding literature, popular culture and contemporary socio-cultural realities of women.

\section{THE CHARACTERISTICS AND HISTORY OF CHICK-LIT}

As a genre of popular literature written for young urban women, the tremendous commercial success of the popular chick-lit fiction inevitably calls for a critical assessment of its status within popular culture and literature. The term chick-lit is derived from the slang word "chick" for a young woman and "lit" which is short 
for literature. It is usually associated with young urban women's culture: chick-lit books typically cover the lives of modern, cosmopolitan, single women in their 20s and 30s who put great emphasis on their dating relationships, careers and shopping. Sarah Mlynowski and Farrin Jacobs define the genre as: "often upbeat, always funny fiction about contemporary female characters and their everyday struggles with work, home, friendship, family or love. It's about observing life and finding the humor in a variety of situations and people" (10). The genre mainly depicts young women working in mainstream media, companies such as publishing houses, glossy fashion magazines, PR firms etc. (Mitchell and Reid-Walsh, 230). Some of the novels such as Bridget Jones Diary take the form of a diary. Others use the confessional style of letters and e-mails, and the intimacy of first-person narrative. Almost all are written in a self-deprecating, funny, first-person voice. Taken as a whole, these works offer the possibility of a fruitful interrogation of the images of contemporary women and their concerns in popular culture, while providing a source of amusement for their readers.

According to Suzanne Ferriss and Mallory Young, the publication of Helen Fielding's Bridget Jones Diary in 1998 in the USA marks the beginning of a trend in women's popular fiction known as chick-lit (2006a: 2). Since the publication of Bridget Jones's Diary, chick-lit has been an increasingly growing popular cultural phenomenon and the publishers discerned a profitable audience for confessional-style novels among women and created new brands of serials such as Gossip Girl (2000--), The Princess Diaries (2000--), Shopaholic Series, as well as The Nanny Diaries, The Botox Diaries and The Dirty Girls Social Club. As Kate Zernike indicates, the genre has experienced amazing commercial success and has caused a "commercial tsunami" (1). Hundreds of chick-lit novels and short stories have been published, translated into many languages and became international bestsellers around the world in the last two decades.

Some writers and reviewers see these novels' roots in the heroine centered novels of the nineteenth century novels like Charlotte Bronte's Jane Eyre and Jane Austen's Nortanger Abbey (Smith 7-8). Indeed, Austen's Elizabeth, Emma and Elinor share many of the same concerns as Fielding's Bridget on the level of everyday life. Fielding herself acknowledges that her book was inspired by Austen's Pride and Prejudice (Smith 7). However, chick-lit differs from those earlier novels by use of humor, self-deprecation and more open attitudes toward sex and material consumer items. According to chick-lit novelist Melanie La'Brooy, chick-lit's greatest achievement is bringing humor into the contemporary women's scene ("Who's afraid of Bridget Jones?"). Indeed, the difference between chick-lit novels and their literary precedents is the ability of the modern protagonists to laugh at themselves. In relation to this aspect of chick-lit Fielding states:

It's good for women to be able to be funny about women and not to be afraid to be funny...Sometimes l've had people getting their knickers in a twist about Bridget Jones being a disgrace to feminism and so on. But the point is, it's good to be able to represent women as they actually are in the age you're living....and laugh at ourselves without having a panic attack. (Quoted in Jones, 2001)

Chick-lit has this mocking attitude toward the authority of the traditional literary fiction and its dominant culture in general. A brief look at these books' candy-colored covers, handwritten script-like titles, cartoon like illustrations and graphics as well as their heavy marketing strategies lets the reader know that they are intended to be popular books, distinguished from the literary ones.

As a popular type of women's fiction, chick-lit has been regarded as similar to traditional romances such as Harlequin novels but chick-lit protagonists, as Bridget Jones of Fielding states, are not like "the flawless women of romance fiction, waiting to be recognized by the perfect man, but women who make mistakes at work, sometimes drink too much, fail miserably in the kitchen" (1996: 2). In terms of desire, sexual agency and experience, chick-lit heroines seem to differ from the naive and innocent heroines of traditional romances. Unlike traditional romances, moreover, contemporary chick-lit doesn't always end in marriage and the heroine's active social life outside her romantic relationship plays an equally significant role in her life. Read this way, chick-lit can be seen as a contemporary ironic critique and subversion of the conventional romances with the romantic ideal of a woman only associated with a man in her life. In addition, Anna Kiernan suggests that conventional romances are either aimed at unemployed women being supported by men or women with low incomes. Chick-lit, on the other hand, is marketed to urban single woman with a spendable income (208).

\section{CHICK-LIT AS A SITE OF STRUGGLE}

\subsection{Criticisms against the genre}

Chick-lit is in fact a very controversial genre. Cultural theorist and sociologist Stuart Hall notes that the structuring principles of popular cultural texts are the "tensions and oppositions" (461). As a form of popular cultural content, I argue, Hall's elucidation also proves valid for the genre of chick-lit. Chick-lit texts' huge 
appeal to contemporary female readers is contrasted by its total disparagement as trivial fiction in literary criticism. Indeed, very few critics have taken them seriously enough to study them in any real depth. While the readers' acceptance and celebration of the genre is inevitable, as Ferriss and Young detail, there are also counter-forces at work dismissing the genre, such as the literary and scholarly apparatuses that continually mark the difference between the valued "serious" literature and the "trivial" chick-lit (2006b). These polarized responses clearly demonstrate that the genre signifies a domain of cultural tension and opposition. The reason why literary criticism does not think of chick-lit fiction worthy of discussion is presumably because of the preference for "high art" and the rejection of pop culture due to the genre's tremendous popularity; its perception as an object of consumption, lightweight, short-lived and highly marketed popular culture trend, rather than an object of art. The obvious commercial success of chick-lit and its rigorous marketing strategies are probably seen as processes that devalue real art and turn it into pure entertainment.

The critics who denounce chick-lit novels tend to read the genre merely as popular literature for female readers who indulge in consumer culture goods, including designer clothes, expensive shoes, trendy accessories and the images of commodified femininity. One example would be Cris Mazza who criticizes chick-lit as a genre populated by heroines "in endless self-doubt, depreciation, and blunder" (18-21). Critically acclaimed novelist Doris Lessing also refers chick-lit as "instantly forgettable books" by declaring that "it's a pity that so many young women are writing like that" (quoted in Ezard, 2001: 7). Lessing further adds that "It would be better, perhaps, if [female novelists] wrote books about their lives as they really saw them and not these helpless girls, drunken, worrying about their weight" (quoted in Ezard, 2001: 7). Scarlett Thomas also mentions the genre's potential to erase all worthier forms of fiction, recommending that women should be protected from reading certain texts and encouraged to read others ("The Great Chick-lit Conspiracy"). Clearly, these criticisms that urge women writers to write and read decent things have an authoritarian quality. Such viewing positions automatically assign anything concerning young women's lives to trifling matter not worthy of consideration and run the risk of dismissing the genre's involvement in contemporary socio-cultural realities of women. They also unavoidably suggest that readers are unknowing victims of manipulation, hence, incapable of making choices for themselves. "Produced by and for women", according to Ferriss and Young (2006: 12), the gendered nature of chick-lit can be one of the major reasons behind its dismissal. In her essay Romance in the Stacks, which appeared in the collection Scorned Literature, Alison M. Scott notes that "the scorn that contemporary romances garner relates substantively to the fact that romances are women's reading...Sociologists have long recognized a phenomenon called feminization, which means that anything that becomes associated solely with women falls in general esteem" (217-8). This may explain why chick-lit novels - of which women are creators and consumers-are being subjected to harsh comments.

Another reason why literary criticism does not regard highly of chick-lit fiction is presumably because of the mass production behind the genre. Considering the contextual issues surrounding the industry of chick-lit, there is no doubt that the marketing of the genre is attuned to a specific demographic and the novels are adapted to the standards set by the commercial market and cultural industries. Thus, in order to fulfill the high market demand many books lacking quality and originality are published. In relation to this, Mitchell and Reid-Walsh indicate that there is a certain formulaic quality to most chick-lit novels which points to the industrial mass production (227). Yet, despite the certain formulas applied in chick-lit as well as the genre's limited focus on contemporary women's lives and the conception of female empowerment, this criticism could be applied to all genres, hence could not be an excuse to condemn the entire chick-lit fiction. There is good chick-lit and bad chick-lit, just as there is good literary fiction and bad literary fiction. The prolific historian Lawrence W. Levine notes that, just because a popular cultural genre is formulaic, it does not necessarily mean that to know any part of it is to know all of it (1374). Levine supplies the example of Schubert or Beethoven quartets; that the reason we remember and appreciate those is not because they are musical compositions without any formulas, on the contrary, these composers succeeded within the very structure of formulas. Thus, Levine argues popular culture deserves the same possibilities (1374). Indeed, the texts of chick-lit novels may be dominated by formulas, but the creative variation of those very formulas within the genre should also be taken into account.

\subsection{Genre's engagement with contemporary women's lives}

Chick-lit may be denounced and dismissed by some critics for the preceding reasons, but it is undeniable that the genre is important as a media phenomenon and social sensation. Chick-lit_-having a long historical origin-is actually a significant cultural mechanism. Analyzing the concepts of femininity developed in contemporary popular fiction and comparing them with the historical fiction can provide insights into how the discourses of marriage, sex, feminism and money evolved in the 200 years between Jane Austen's Pride and Prejudice and Helen Fielding's Bridget Jones's Diary. Thus, a critical analysis of this popular fiction holds 
the possibility to reveal how the genre reflects and comments on contemporary social developments. Julia MacDonnell, an academic who sees value in chick-lit, argues that the genre is full of "witty, ironic stories about idiosyncratic heroines". The stories, she claims, are "not merely entertaining but also offering insights into how we live now" (quoted in Ward). In addition to that, a serious consideration of chick-lit reveals issues that many contemporary young women struggle in terms of identity and femininity, and exposes insights about contemporary women's lives, their careers and relationships. Imelda Whelehan also points out to this aspect of these popular novels, by mentioning how they shed light on the lives and concerns of modern young women, as well as the social and cultural factors such as consumerism, media images, plastic surgery, job opportunities, gender roles and self-identity (2005: 4-5). According to Whelehan, the genre reflects the anxieties of today's "transitional" women who feel stress and ambivalence about identity, sexual agency as well as the attractions or perils of work, marriage and motherhood (2005: 5). Indeed, the genre often depicts the romantic tribulations of young, single, heterosexual, urban heroines in their twenties or thirties. Thus, these novels become the expressions of how women see each other, themselves, their relationships, work and family life. For instance, I Don't Know How She Does It by Allison Pearson explicitly tackles the problems that young women face, struggling to balance challenging careers and personal lives centered on the pursuit for a satisfying romantic relationship. Carrie Bradshaw's column "Sex and the City", moreover, in the fictional New York Observer newspaper in Candace Bushnell's Sex and the City is the product of her personal search to assess contemporary cultural and sexual norms for young women in Manhattan. "The question of the week" in her column, which searches for the answers to questions such as how to remain friends with an ex-boyfriend and how many sexual partners are too many, reflects the attempts of many real life modern women to negotiate their relationships and gender roles, and to determine their place within those relationships. Ultimately, the genre engages with and responds to the many contradictions and tensions between contemporary society and young women's lives.

Chick-lit novels may also engender identification processes for women who look for emotional and social bonds with other women, by means of being more supportive and less competitive of each other. Many of these novels promote the value and benefits of female friendship and support, which might be considered as an empowering practice that resist patriarchy. They can also be seen as a way to start dialogue about women's experience as underlined by Mitchell and Reid-Walsh: "When young girls can share their understanding of teen literature with their mothers, there is a real potential for discussion of contemporary girl issues...Evaluating the space that crossover readers inhabit together can lead to a better understanding of how girl and womanhood are constructed" (253). This view illustrates how chick-lit could be employed in literary and scholarly criticism to explore generational differences in feminism. Therefore the genre can shed light on how both young girls and women make meaning and negotiate their identities through reading these popular cultural texts. It follows from all this that, chick-lit is more than plain entertaining or marketing plans' of publishing industries, hence deserves a critical consideration. In relation to this, Levine asserts people's ability to refashion and reinterpret popular cultural texts created for them by the powerful producers to fit their own values, needs and expectations (1373-74). He further mentions audiences' processes of selection between what they find meaningful, appealing and functional and what they do not in every popular genre. It is clear that the readers of Bridget Jones are not simply gullible victims and they cannot be regarded as passive, undiscriminating consumers addicted to trivial fictions. Rather, these women find a space to explore their own feelings and experiences in their daily lives regarding gender roles, relationships, sexuality, and career etc. via the characters of these popular cultural texts. In a similar way Levine conceptualizes the realm of popular culture as creating a "profoundly close relationship between the audience and the meaning of the text" (1379), there is a dynamic connection that exists between the female readers and expressive chick-lit texts with which they interact.

The struggles and dilemmas faced by the young women characters in the narratives of chick-lit novels can be exemplified by the dissatisfaction with their bodies and their relationships, mandates about the female body and their discomfort with career aspirations. For instance, Bridget Jones turns to other magazines and programs that give information to perfect her body through exercise, dieting etc. Only after perfecting her body according to these standards, she gets ready for her date. Consumer culture mediums from magazines to self-help books have a strong hold on Bridget's life. By sharing the details of her problematic relationships, her job and failed attempts to reduce her consumption of alcohol, cigarettes and calories, she gains women's empathy. As Whelehan asserts, in our era, young contemporary urban women who embrace the traditionally masculine lifestyle choices such as excessive drinking, socializing and casual sex and indulge in the pleasures offered by consumer society became current in popular culture (2000: 93). This clearly demonstrates that the protagonists are not only the products of their authors, but they also reflect their reading audience. In other words, the chick-lit texts are directly connected to their readers insofar as they invite them to identify with the characters and situations portrayed and to see them as reflective of their own lives in the way personal and social problems are handled. As put forward by Ferriss and Young, the heroines of chick-lit novels further elicit reader identification through their fallibility and self-deprecating humor-something that is missing from the conventional romance novels (2006: 4). As a flawed 
character, they state Bridget induces most readers' empathy and recognition of their own feelings (2006: 4). Thus, it seems reasonable to argue that the women who read these books are, in many ways, like the women depicted in them; young, relatively successful but somewhat insecure, prone to romantic weaknesses, looking for fiction that serves as both entertainment and guidance.

\subsection{Chick-lit as a "functional" text}

According to media scholar John Fiske, viewers of media culture or readers of popular literature practice a selective style of apprehension, filtering out undesirable dominant ideology and adapting the original or obvious message for something that is more appropriate to their particular reality. He terms this way of reading, which focuses on what is relevant to the reader's circumstances, a resistance to the flood of mass culture (1987: 137-8). Within that framework, it can be claimed that chick-lit can be functional and relevant by reflecting women's lives as well as being entertaining at the same time. As Fiske asserts, in popular culture, social relevance and function are "far more powerful that textual structure" and "popular is functional" (1987: 105). Indeed, women use these popular cultural texts in making sense of their own social experience and thus coping with their urban lifestyles in which they are caught up in between the contemporary modern lives and the traditions that still expect them to maintain a conventional femininity. The female readers accept the chick-lit texts according to their needs, thus, these texts, I argue, are functional and socially useful in meeting the negotiations and challenges that women's daily lives involve. The female readers construct relevance between the lines of the chick-lit novels and their own conditions of living. In this respect, the enjoyment of books, which may not be considered respectable in a literary sense, is still something worthy because chick-lit books can be characterized as functional. Arguably, what makes these books pleasing for readers is the way they negotiate the elements of contemporary women's lives and relationships in regard to men and to the offerings of consumerism in humorous and non-didactic ways. Surely, this research needs a further assessment of what readers think about the significance of chick-lit in their lives and the culture they are embedded in, but upon evaluating the scholars' views, as well as the print and online book reviews, news articles, blogs and personal sites about chick-lit, this implication becomes evident.

\subsection{Potential spaces for resistance}

In terms of feminism, some critics are also disturbed by the genre's commercialized representations of femininity. The term "chick" itself implies immediate negative reactions. The term and reactions to it point to some of the larger issues involved in responses to chick-lit. According to Ferriss and Young, the contemporary usage of this term signals infantilizing of women, girlifying representations of grown women and a failure of their efforts to create a society based on gender equality (2007: 3). In that sense, debates on chick-lit partly amount to the struggle over the politics of representation of women, gender and sexuality. The reason for such criticism is probably due to the genre's depiction of women's empowerment as purchasing power, and their identity as being intimately linked to liberated sexuality and consumer capitalism, while lessening the need for social change to improve women's lives. One might raise a critique towards this argument that, chick-lit, in fact, deals with issues essential to feminism such as the pressures on women about the body mandates and balancing work with intimate relationships. The protagonist of Allison Pearson's I Don't Know How She Does It asks for instance, "Back in the seventies, when they were fighting for women's rights, what did they think equal opportunities meant: that women would be entitled to spend as little time with their kids as men do?" Another example could be about self-surveillance; while Bridget Jones confesses that she has "been traumatized by supermodels", the beauty routines and obsessive counting of calories are heavily parodied in later chick-lit. Again, oversize characters of Jennifer Weiner's novels express their sorrow about the injustice of being compared to impose beauty standards. Sophie Kinsella's Confessions Of A Shopaholic and the rest of the Shopaholic series, with their heroine driven into credit card debt by her shopping sprees, lead us to ask if female consumers are self-actualized agents or society's victims (Ferriss and Young, 2006b). Similarly, the excessive references to the protagonist Maya's indulgence in elite commodity consumption in Sonia Singh's Goddess for Hire, one of the most popular South Asian-American chick-lit novels published in the U.S, might also be read as a parody and subversion of a number of chick-lit conventions regarding materialism and consumer culture. Thus, somewhat paradoxically, the genre provides women readers with a humorous relief from the demands of being smart, trendy and sexy altogether, while also satirizing the chick-lit conventions. These examples clearly demonstrate that, chick-lit writers also create protagonists who express concerns that suggest potential spaces for resistance and processes of misidentification for readers. There are some features of these texts, then, which can go beyond the efforts of their publishers to unify them for the sake of capitalism. Put another way, in a variety of ways chick-lit seeks to challenge cultural expectations about women as consumers, readers and writers, as well as about the popular fiction itself. Rather than being as an absolute disloyalty to feminism, therefore, such examples suggest that chick-lit fiction, at least part of it, is also capable of opening up spaces for negotiating the contradictions of contemporary feminine subjectivities as well as the mainstream ideologies of the society. In relation to this, Young 
and Ferriss also mention the proliferation of the chick-lit novels in diverse cultures: "Instead of continuing to get that very same Bridget Jones clone again and again, we're getting some different versions" (2006a: 6-7). Indeed, since its flourishing from the late 1990s, other variations in the genre such as mum-lit, work-lit, slut-lit have also published as well as ethnic sub-genres. As Butler and Desai articulate, "Chica-Lit and Sistah-Lit also tell stories about young women's individual empowerment, but the characters' engagements with femininity and gender are often articulated through questions of race, nation, ethnicity, and socioeconomic class" (4). Before dismissing the entire genre into one category as formulaic, therefore, one has to also acknowledge how these sub-categories differ from the mainstream chick-lit in terms of nation, culture, ethnic identity, religion and plot, and how they can shed light on the cultural mechanisms of the specific society that produces them.

\subsection{Chick-lit as a feminine "tactical response"}

French scholar Michel De Certeau suggests that certain activities that are part of the "practices of everyday life" could be seen as tactical maneuvers or even forms of public rhetoric rather than passive behavior that signals acceptance of the status quo (18). By using these everyday practices, people in subordinate formations negotiate, challenge and oppose these structures. In a similar manner conceptualized by De Certeau, it is likely that women who read chick-lit enjoy the imaginative possibilities the genre offers and indulge in the empathetic experience that aids them in returning to and negotiating the challenges that they face in contemporary life. These texts become vehicles that their readers fit into a meaningful and significant context, depending on their own experiences, needs and expectations. In other words, women become "poachers" of textual meanings, as De Certeau would describe, by extracting the things that seem useful or pleasurable to them from those texts and appropriating them to their own ends in order to make sense of their own social experience (175). The pleasures, entertainment and meanings generated by the practice of chick-lit reading, then, can be recognized as offering a space for cultural maneuver. Read this way, the very practice of women's reading chick-lit can be considered, in Fiske's words, as a minor feminine "tactical response that enable them to deal with it on a day-to-day level" (1989: 321), as well as an act of negotiation of their everyday life structures. This is not to propose that this actively engaged reading process is necessarily subversive or progressive, but at the very least, as Fiske argues, such tricks can serve as tactics that maintain the morale of the subordinate (1989: 321). Put another way, these popular cultural texts might offer a sort of enhanced morale and motivation to their women readers in their negotiations of daily life.

\subsection{The interplay between "consent and resistance"}

The active process of reading and generating meanings that exists surrounding chick-lit novels can further be discussed within the framework of the critical position Hall provides. Hall underscores that, "there is no whole, authentic, autonomous 'popular culture' which lies outside the field of force of the relations of cultural power and domination" (460). Indeed, as discussed elsewhere in this paper, the power of cultural implantation by the mass production and the publishing industries behind the chick-lit genre should be acknowledged. These cultural industries and publishers "impose and implant" those dominant or preferred culture (Hall 460). However, this form of commercially provided popular culture, according to Hall, is not purely manipulative and does not function as if the viewers or readers are "blank screens" (460). In chick-lit fiction, to follow Hall's account, there are also "elements of recognition and identification, something approaching a re-creation of recognizable experiences and attitudes to which people are responding" (461). Denouncing chick-lit novels as vehicles of cultural industries and affirming the notion of people as purely passive recipients, therefore, do not provide us with an adequate account of the cultural relationships formed around the genre. It follows from all this that, the genre of chick-lit might be construed as a deeply contradictory site; a site of dynamic interplay between "consent and resistance" since it functions in the domain of "popular" (Hall 466).

\section{CONCLUSION}

In the light of the preceding discussion, viewing chick-lit as a threat to "serious" literature and to the minds of its female readers, as well as recommending women to engage in decent reading and writing activities run the risk of ignoring some of the very important ways in which these popular cultural texts provide insight into the cultural mechanisms, contemporary social developments and feminine subjectivities. Such dismissals also underestimate the ways in which popular culture acts as a site of production of and contestation over meanings. As discussed elsewhere in this paper, the practice of reading chick-lit may reveal opposition as well as conformity to the structures of power. In that sense, to view chick-lit either from an entirely negative or positive perspective would be to oversimplify both the genre and the issues related to literature. The culture industry fostering chick-lit books for profit as well as heavy marketing techniques, formulaic qualities and cultural implantation by the publishing industries are all part of the chick-lit reality, but when looked beyond these, the genre of chick-lit provides a powerful lens to view contemporary socio-cultural realities of women and the issues they face in the everyday lives they are embedded in. 


\section{REFERENCE LIST}

Mlynowski, Sarah \& Jacobs, Farrin. See Jane Write: A Girl's Guide to Writing Chick-lit. Quirk Books, 2006.

Mitchell, Claudia \& Reid-Walsh, Jacqueline. Girl Culture. Greenwood, 2007.

Ferriss, Suzanne \& Mallory Young. Chick-lit: The New Woman's Fiction. New York: Routledge, 2006a.

--- "A Generational Divide Over Chick-lit". Chronicle of Higher Education. Vol. 52, No. 38, $2006 \mathrm{~b}$.

--- "Chick Flicks: Contemporary Women at the Movies." Routledge, 2007.

Zernike, Kate. "Oh, to write a "Bridget Jones' for Men: A Guy Can Dream.” 22 February 2004. 9.1-2. New York Times. 20 May 2009 <http://www.nytimes.com/2004/02/22/style/oh-to-write-a-bridget-jones-formen-a-guy-can-dream.html

Smith, Caroline J. Cosmopolitan Culture and Consumerism in Chick-Lit. Routledge, 2007.

La'Brooy, Melanie. "Who's afraid of Bridget Jones?” 11 December 2005. The Australian. 1 May 2009

< www.theaustralian.news.com.au/story/0,25197,17179744-32542,00.html>

Jones, R. “Female Fiction Dumbs Down”. 23 August 2001. BBC News. 22 May 2009

< http://news.bbc.co.uk/1/hi/entertainment/arts/1504733.stm.>

Kiernan, Anna. "No Satisfaction: Sex and The City, Run Catch Kiss and the Conflict of Desires, in Chick-lit's New Heroines." Chick-lit: The New Women's Fiction. ed. by S. Ferriss and M. Young, New York: Routledge, 2006.

Hall, Stuart. "Notes on Deconstructing the Popular". People's History and Socialist Theory. London: Routledge, 1981.

Mazza, Cris. "Who is Laughing Now? A Short History of Chick-lit and the Perversion of the Genre." Chick-lit: The Scott, Alison M. "Romance in the Stacks, or, Popular Romance Fiction Imperiled." Scorned literature: Essays on the History and Criticism of Popular Mass-produced Fiction in America. Westport, CT: Greenwood Press, 2002.

Ezard, J. "Bainbridge Tilts at Froth”. 24 August, 2001. The Guardian. p. 7. 22 May 2009

< http://www.guardian.co.uk/uk/2001/aug/24/books.generalfiction>

Thomas, Scarlett. "The great chick lit conspiracy". 4 August 2002. The Independent. 20 May 2009 $<$ http://www.independent.co.uk/arts-entertainment/books/features/the-great-chick-lit-conspiracy638935.html>

Levine, Lawrence W. "The Folklore of Industrial Society: Popular Culture and Its Audiences." The American Historical Review. Vol. 97, No. 5, 1992.

Ward, Alyson. "While some predict an early death for the new genre of 'chick' literature, others say it's an Industry that's just started hatching." 9 August 2003. Star-Telegram.

<http://search.ebscohost.com/login.aspx?direct=true\&db=nfh\&AN=2W73016135558\&site=ehost-live >

Whelehan, Imelda. The Feminist Bestseller: From Sex and the Single Girl to Sex and the City. New York, 2005.

--- Overloaded: Popular Culture and the Future of Feminism. London: Women's Press, 2000.

Fiske, John. Understanding Popular Culture. London: Routledge, 1987.

--- "Shopping for Pleasure: Malls, Power and Resistance." Reading the Popular. Boston: Unwin Hyman, 1989.

De Certeau, Michel. The Practice of Everyday Life. University of California Press, 2002.

Butler, Pamela \& Desai Jigna. "Manolos, Marriage, and Mantras: Criticism and Transnational Feminism." Meridians: Feminism, Race, Transnationalism. Vol. 8, no. 2, 2008.

Fielding, Helen. Bridget Jones's Diary. New York: Penguin Publishing, 1996. 